\title{
Importance of Social Media as Communication Channel in Bank Marketing
}

\author{
Asst. Prof. Dr. Aziz Öztürk
}

\author{
Selçuk University Beyşehir Ali Akkanat Faculty of Business \\ azizozturk@selcuk.edu.tr
}

Ömer Faruk Güven

Doi:10.5901/ajis.2014.v3n3p76

\author{
Selçuk University
iven@hotmail.com
}

\section{Abstract}

\begin{abstract}
Simplex transmission means such as advertisement and other promotion activities are no longer efficient for the banks. To increase the efficiency in promoting and communicating, simplex transmission activity should be converted to a communication activity. Target is not the "mass" but the "individual's in today's banking business. Because of these reasons it is a necessity to reach individuals, determine their expectations via specialized tools, and build up strategies for these expectations. Social media helps banks to produce concurrent, effective and fast solutions with its opportunities for practicing the aimed communication at this level. In addition, it became a solution partner as a flexible and low-budget communication channel. Wide properties of social media tools are going to surpass present media tools as "classical media" and be a pioneer in developing these kinds of new generation tools as "neo-media".
\end{abstract}

Keywords: Marketing, Social Media, Bank, Communication, Competition

\section{Introduction}

Innovations and developments in social media environments are becoming effective in meeting the needs of the individuals in sharing and socializing. Social media is generally around Facebook and Twitter, but it includes very large amount of different platforms ${ }^{1}$. Social media is a media system which enabled people communicate bilaterally and simultaneously after the launch of web $2.0^{2}$. Social Media can be evaluated as a postmodern reflection of the internet and a new civilisation by its new features.

Use of social media by the firms as a part of communication channel could be explained by its cumulative properties which were designed by $\mathrm{M}$. Fruchter as $5 \mathrm{C}$. These are; Conversation; mutual unlimited communication and sharings, community; communities with common interests, commenting; comments to other sharings, collaboration; accord and co-operation, contribution; response and contributions ${ }^{3}$. Unlimited accessibility, personal interface, customizable toolkits, user numbers, measurable feedbacks and finally often updated dynamic structure of social media has created 4 , the concepts of "Content of the Users" and "the Media Produced by the Customers". Its importance increased in the commercial life by this structure ${ }^{5}$. Although face to face communication is the most reliable way for most of the enterprises and persuasion process works better with this method, technology included various environments and media channels into the communication methods of the enterprises ${ }^{6}$.

\footnotetext{
${ }^{1}$ http://www.sosyalmedyal.com, "Sosyal medya nedir?", (http://www.sosyalmedyal.com/2012/10/sosyal-medyanedir.htmH.Uq3wyZBL5Ro) E.T. 10.11.2013

2 http://tr.wikipedia.org, Sosyal Medya, (http://tr.wikipedia.org/wiki/Sosyal_medya) E.T. 09.10.2013

${ }_{3}$ Mike Fruchter, "Marketing On The Social Web: A Few Key Ingredients" 3 February 2009, (http://www.michaelfruchter.com/blog/) E.T. 10.09.2013

${ }^{4}$ Burak Bayburtlu, "Sosyal Medya Nedir?", (http://www.burak.com/2009/06/23/sosyal-medya-nedir) E.T. 06.10.2013

${ }_{5}^{5}$ M. Andreas Kaplan, "If you love something, let it go mobile: Mobile marketing and mobile social media 4x4", Business Horizons, 55(2), 2012, p. 129-139.

6 Özgen ve Doymuş, a.g.e.,s.92
} 


\section{Change in Marketing Communication}

Nowadays it is quite difficult to reach the target community by a true channel effectively due to communication opportunities increasing and diversifying rapidly. In addition to this, cost of access increased but on the other hand communication demands of consumers increased and varied as well. These changes expedited the searches on communication and as result of these searches the term Marketing Communication (IMC) emerged ${ }^{7}$. Marketing communication comprises all marketing components and actions. It also comprises versatile informative, persuasive and reminding actions. When it is considered from this point of view, marketing communication is all of the efforts of communication which is used to provide information about what the enterprise promise and supply to its target ${ }^{8}$. Marketing communication is effective in both sending messages to the customers and acting in a line with the responses received from the customers. Thus, while the enterprises have the opportunity of giving the better information about their products to the customers they have chance in evaluating and changing their products and their messages according to the demands of their customers 9 .

Banks should apply customer centred strategies instead of sales centred communication strategies in their IMC efforts. The event of communication is tried to be practised as process and concept in marketing communication. By its process side, enterprises aim at an approach which is going to contribute the institutional identity and use of communication in an administrative sense. By its concept side, enterprises aim at a general synergy which will provide unity with the all marketing communication activities creating supremacy and differentness and marketing mix ${ }^{10}$.

Communication activities of companies focused on advertisement and advertisement became mostly and most frequently used communication channel towards 2000 s by the development of media tools. But in the next periods the internet took its place as the most effective instrument of the advertisement World. Advertisement has not got a «communication» property but a «transmitting» property since it is a one sided promotion activity. To add «communication» feature to this promotion activity which has problems in measuring the event and creating the expected impact could only be possible by the development of the internet.

Since advertisements are broadcasted in many different places in different formats along with a lot of other advertisements, many advertisements for only one aim cause ineffectiveness of them. And advertisers want to reach their customers in a more effective way with rational advertisement budgets. More than half of the advertisement expenses are used on televisions. Other half of the advertisement expenses are used on printed media. But while television advertisements are increasing their share, printed media began to take less share from the advertisements. Instead of printed media advertisements enterprises began to use more open air public advertisements. Nowadays internet advertisements are the fastest growing sector of all ${ }^{11}$. Advertisement has gained an informative and communicative property after the use of toolkit applications of social media tools as a one sided communication tools.

Banks have to compete with the other brands and their products in advertising their products and services to their target groups ${ }^{12}$. Besides, when the target group showed an act of avoiding the advertisements, the enterprises began to search for suitable and effective tools for reaching the customers. Because many people consider that the advertisements are the legal ways of telling lies ${ }^{13}$.

Avoiding advertisements has been a problem for a long time and it is a natural reaction of people against information overload. People want to get rid of advertisements when they are not suitable for them and disturbed by the unwanted ones. As a result of this act they may miss the advertisements which could attract their interests. Speck and

\footnotetext{
7 Communication Partner, "Doğru ve etkin bir iletişim pazar payınızı artırı." http://www.cpartner.com.tr/pazarlama-iletisimi/ E.T. 20.11.2013

${ }^{8}$ Haluk Mesci, Reklamcılık, T.C. Anadolu Üniversitesi, A.Ö.F. Yayını, Eskişehir, Ekim 1984, s.2

9 S.Inci ÇELEBi, Pazarlama Amaçlı Halkla Iliş̧kiler ve Bütünleşik Pazarlama İ̧indeki Rolü, Yüksek Lisans Tezi, Ege Üniversitesi, İmir, 1999, s.10

10 Mustafa Duran, "Pazarlamada Yeni Bir Boyut: Bütünleşik Pazarlama Illetişimi", Pazarlama Dünyası, (http://www.pazarlamadunyasi.com/Default.aspx?tabid=203\&/temld=159) E.T. 11.02.2013

11 Cihad Yağmur Sadıkoğlu, "Reklamın Dönüşen Yeni Mecrası Açık Hava Reklamcı̆ığı ve Etkileri", Işsetme Anabilim Dalı, Anadolu Üniversitesi Sosyal Bilimler Enstitüsü, Şubat 2013, (http://Acikhava-Reklamcilik.Webnode.Com.Tr/Makaleler) E.T. 09.08.2013

12 Elif Uğurlu, "Reklamın Insan Üzerindeki Etkisi", (http://okumagunlukleri.blogspot.com/2011/06/reklamn-insan-uzerindeki-etkisi.html) E.T. 01.11 .2013

${ }^{13}$ Hugh Michael Jackman, Avustralyalı aktör ve yapımcıdır. Wolverine'i canlandırdığı X-Men filmlerinin dışında başrolde oynadığı Kate \& Leopold, Van Helsing, Prestij, Avustralya, Çelik Yumruklar, Sefiller ve Prisoners filmleriyle tanınır. Sefiller filmindeki performansı 2013'te ona En lyi Aktör dalında ilk Akademi Ödülü adaylı̆̆ını ve Müzikal veya Komedi dalında En lyi Aktör dalında Altın Küre ödülünü kazandırdı.
} 
Eliot accept the advertisement as a thing which damage the communication and a significant source of noise ${ }^{14}$.

\section{Importance of Social Media in Bank Marketing}

Since banking is an area of service in which personal communication is used densely, it is essential to determine the needs of the customers well and present the most suitable servicing to the customers ${ }^{15}$. For this purpose, the social media which is used to determine and evaluate the expectations should be significant along with the netnography which is one of the qualitative methods.

Netnography is the branch of ethnography that studies the behaviour of individuals on the Internet. Netnography is the technic which adapts current ethnography research technics to online groups. It is generally defined as a new research method developed from ethnography in order to understand today's customers who are very social among online societies ${ }^{16}$. Nowadays social media increases its importance in converting the digital data of target group to marketing and sales tools as a direct channel.

At this stage banks are trying to do penetration to this type of customer segment in order to enable synergies that is based on the assumption of few people with so much potential that is defined essentially as "great mass" with social media and having a lot of money and to be effective in content marketing ${ }^{17}$. Briefly, content marketing recommends person or the companies to act as the publisher and consists of three stages: i)to create a content that is meaningful to a specific audience, interesting, valuable and original, ii) to deliver this content to the target audience in an organized and systematic style, iii) to promote individuals in the target audience to read, to watch, to listen, to think and to act in accordance with this content ${ }^{18}$.

Social media strengthens its presence as a tool of new generation of media in ensuring the customer to become acquainted with the service and sustainable user for the banks. Thus, banks prefer to take place in the social media, that the masses widely use and follow, in order to reach the great mass. While doing this preference, they are especially prominent with content marketing in social media.

Social media means the new information source of which content created and shared by consumers, informing and educating consumers about brands, products, services, ideas, and a variety of social problems from the standpoint of marketing communication. Blogs including digital audio, video, and movies, bulletin boards supported by the enterprises, chat rooms, e-mail systems from consumer to consumer, web sites where the products and services are rated, forums, micro-blogs like Twitter, social networking sites like Facebook, MySpace and Bing take place among these ${ }^{19}$.

While advertisement is having chronic problems mentioned above, the banks discovered the social media which adds dimension to their marketing strategies ${ }^{20}$. Social media is very appropriate for banking services, because of its this kind of property it enables a sustainable communication between banks and customers.

Elements which makes the use of social media and the investment necessary can be listed as follows;

- Banks are the corporations about which opinion is most reported and touching all sections of society in a way. Social media has most effectively become a course of listening, understanding and monitoring the customer for the banks.

- It is benefited significantly from the social media tools for the innovation of alternative banking applications that social media offers. Thanks to the advertising and campaigns, the products and services offered to target customer groups by social media, customers are being informed of promotions, discounts and developments which only concern themselves.

- Also, customer can communicate with the bank and send their complaints and suggestions to the customer

\footnotetext{
${ }_{14}$ H. Kemal Suher ve N. Bilge İspir, "Televizyon Ve Gazetede Reklamdan Kaçınmayı Etkileyen Değişkenler" Selçuk Üniversitesi, İletişim Fakültesi Akademik Dergisi, ISSN 1302-2865, Ocak 2010, Cilt; 6, Sayi; 2, s.6

${ }^{15}$ Aziz Öztürk ve Ömer Faruk Güven, Bankacılık ve Sigortacılıkta Pazarlama, Beta Yayım A.Ş., İstanbul 2014, s.278.

${ }_{16}$ Gresi Sanje Dahan ve Eser Levi, "Netnografya: Sosyal Mecralarda Tüketici Araştırmaları Üzerine Yeni Bir Meto", T.C. Gümüşhane Üniversitesi, İletişim Fakültesi Elektronik Dergisi, Mart 2012, Sayı;3, s.35

${ }^{17}$ Emre Haliloğlu, "Finans ve Bankacılık Sektöründe Içerik Pazarlaması", Eva İstanbul İçerik Ajansı, (http://blog.turkcell.com.tr/finans-vebankacilik-sektorunde-icerik-pazarlamasi) E.T. 11.05.2014

18 Mike Sweeney, "What is Content Marketing and Why is it Hot?", Marketing Strategy, Fabruary 10, 2010, (http://www.rightsourcemarketing.com/marketing-strategy/what-is-content-marketing-and-why-is-it-hot/) E.T. 11.05.2014

${ }^{19}$ Özgür Köseoğlu, "Bir Pazarlama Illetişimi Ortamı Olarak Facebook: Reklâm Ve Elektronik Ağızdan Ağıza Mesajların Karşılaştırılmasına Yönelik Bir Analiz" Global Media Journal, ISSN1309-7601, Cilt; 3, Sayı; 6, Bahar 2013, s.76

${ }^{20}$ Burcu Illter ve Habil Gökmen "Mevduat Bankalarında Illişkisel Fayda ile Müşteri Memnuniyeti Arasındaki Ilişsi Üzerine bir İnceleme: İzmir Ili Örneği”, Dokuz Eylül Üniversitesi, Sosyal Bilimler Enstitüsü Dergisi, Cilt: 11, Sayı:1, 2009, s.5
} 
satisfaction section. These increase the degree of satisfaction by monitoring continuously and returning to the customer in a short time.

- It makes inevitable the competitive environment with the number of customers and including different customer profiles in the banking sector. Banks can easily share their campaigns or advertisements with millions of customers by social media in this competitive environment and access instantly to their customers. Social media is an important course for banks in establishing deeper relationships with customers, recognizing them, understanding, shopping, monitoring investment objectives and complaints management. Some banks are also developing applications that provides customers, who save targets and share via social media, to ask for help from friends.

- The social media data also taking place in the solutions offered, provides an opportunity to be able to make more personal campaign and activities by creating new and micro-segments, enrichment of customer data by collecting the contents like customers ' life style, preferences, the places where they are, comments they make,

- Thanks to the MobileBank applications developed in Facebook and Twitter, customers can also transfer money from social media. Customers are able to add units to their or someone's account, even they are able to share and pay the accounts coming to the table immediately at dinner. Again, anyone, whether or not the bank's customer, has the opportunity of following current market news, accessing shares information, applying for a credit or credit card at their computer with developed table top applications.

Banks are found in act of "chase " with advertising and other one-way promotional activities. That may cause inefficiency and waste in planning of resources rationally and gauging repatriations. Hence, short-term business trends should be used instead of chasing. And the way of it is the use of the social network which allows to obtain the furthest feedback in communication. At the future not too distant, media tools known in promotional tools are going to be memorialized as "Old type" media and personalized promotional tools are going to return to "neo media" under the leadership of the social media.

\section{Use of Social Media by Banks}

Turkish banks have begun to take part in social area recently. Since Turkish people are number one in spending time on internet in Europe ${ }^{21}$, banks began to give importance to social media more than ever. In addition, the internet users in Turkey who are mostly interested in social media spend their one hour for internet and $24 \%$ of them write personal blogs. This ratio is higher than the Europen average ${ }^{22}$.

Mobile Banking is very popular among young users according to a survey which was conducted by ING Group on "Mobile Banking, Social Media, and Financial Behaviour". 51\% of the young people in Turkey would like to pay their payments via social media. According to the survey, the people getting in touch with their banks by social media and using mobile banking services feel themselves confident in managing their money. 39\% of the survey participants use social media to get general information about the bank, $32 \%$ use it for their complaints, $31 \%$ use it for assistance and communication with the bank. According to survey results the clues about saving money are number one among the expectations of the customers. According to results, young people expect paying their payments via social media. $51 \%$ of the young bank customers in Turkey hope to pay their payments by using social media ${ }^{23}$.

According to the survey conducted in Europe, the Middle East and Africa within 38 countries as well as in Turkey in more than 70 banks about "customer focuse in retail banking" by the European Financial Management Association (EFMA) and Peppers\&Rogers Group, banks use social media platforms for two-way customer communication. Mostly used social channel is Facebook with $84 \%$ ratio, Twitter-63\%, YouTube 54\%, and Linkedin- $42 \%$. In this level, customer relations activities are carried on as one way communication activity such as sending promotion messages to the customers or customers' messages about their complaints and demands. Banks usually watch on the comments and complaints on Facebook and Twitter. Facebook is used wider than the other channels but Twitter is used more effectively

\footnotetext{
${ }^{21}$ Z. Beril Akıncı Vural ve Mikail Bat, "Yeni Bir Illetişim Ortamı olarak Sosyal Medya: Ege Üniversitesi Illetişim Fakültesi'ne Yönelik Bir Araştırma", Journal of Yaşar University, Sayı: 20, No: 5, 2010, s. 3353.

22 (http://smgconnected.com/turkiye-diger-ulkelere-gore-e-ticaret-ve-sosyal-medya-kullanimindahangi -noktada) E. T. 09.09.2012

23 ING Bank Basın Bülteni 29 Haziran 2013, "Gençler Ödemelerini Sosyal Medya Aracılığıyla Gerçekleştirmek İstiyor", (http://www.ezonomics.com/img/iis/ingbank_bb_iis_180613_(2).pdf) E.T. 15.05.2014
} 
in meeting the complaints ${ }^{24}$.

Facebook like numbers, Twitter follower numbers, Twitter Klout scores, websites Alexa ranking, mostly used apps from Apple Store, research numbers on the internet of the banks will help understanding the rise of the social media.

Number of Facebook users in Turkey is 33 million in late 2013. Turkey is 1st in Europe and 6th in the world in terms of Facebook user number. In addition, six million people use Twitter actively in Turkey ${ }^{25}$.

Fan of the banks on Facebook is 9million in Turkey at the end of 2013. First three banks are; 1- Garanti Bank: 1.480.000, 2- Akbank: 1.460 .000 and 3- TEB: 910.000

486.000 people follow the banks on twitter at the end of 2013. First three banks and number of their followers are: 1- Garanti Bank: 98.000 2- İşbank : 51.000 and 3- Yapı Kredi Bank : 39.000.

Also, there are 3 Turkish banks (Garanti Bank, İşbank, and Yapı Kredi Bank) in the top 100 of Alexa Web Site ranking. Mobile banking applications of 4 Turkish banks (Finansbank, Garanti Bankası, İşbankası and Akbank) are in top 100 list of the world banks.

\section{Conclusions}

Social nets are gaining importance as an information source. Besides, social media channels let the customers express their positive or negative opinions more freely. Use of social nets for different banking activities by the customers is a common trend among the countries participated the surveys of the subject. According to the results of Global Private Banking Survey which was conducted by Ernst\&Young; $44 \%$ of customers use social media tools to get information about private banking. Turkey is in a leading position for this kind of use in the world. $78 \%$ of the consumers use social media to get information about banking services. 53\% of the customers use social media to express their opinions about the service they had from their banks. In addition to these results, customers demand flexibility in using different channels for different kind of operations ${ }^{26}$.

Social media is a kind of flexible low budget channel for the banks where they could present their innovative behaviours freely, contact the customer in promotion and communication process, and regulate their services according to the demands of their customers freely without a limitation. Also it is a box of ideas in which they can store not the ideas of a research-development team but the ideas of millions of customers. Social media is more effective than the classical promotion activities for the banks. Because target group takes part in these activities willingly. From this aspect, it is possible that advertisement media will gather in the middle of the social media or close to it.

The competition among the banks are in a different dimension today because the banks are semi-public institutions and they are strictly observed and advertisement and promotion activities resemble each other very much. For this reason, price, delivery and service type of activities are not the tool which determine the competition. Competition evolved in the direction of touching the customer and meeting the expectations. As a result of this process, social media became a "solution partner" and these solutions carry out the marketing communication in the expected way. Thus, the data obtained from the marketing communications and the tools providing the communication take a different place among competition tools as an important competition field.

By analysing interests, demands and behaviours of the customers via social media, products and services for the target can be presented and the feed backs of these activities can be obtained fast and transparently. The banks which want to apply social media analyse should draw a road map to determine how to use the data of the customers. This road map provides reaching maximum benefits in a best way. While carrying out customer data analyse it is seen that presenting products and services which were classified according to customer's behaviours before is a very innovative act. Banks could only analyse and classify the customers' data by a true planned technological infrastructure. Presenting proposals by associating it with strategy, developing products which could provide add value, marketing all these services and products help the management of customer relations ${ }^{27}$.

24 Tunç Akyurt, "Küresel bankacılığın yükselen değeri, Müşteri odaklı yaklaşım",Payment Systems Magazine (PSM), (http://psmmag.com/haber/musterileri-boyle-elinde-tutacak/590909) E.T. 10.05.2014

${ }_{25}$ http://www.socialbakers.com ,Regional Reports: Turkey, Socialbakers Socıal Media Report, November 2013, (http://www.socialbakers.com/knowledge/reports/regional/november-2013-social-media-report-facebook-pages-in-turkey) E.T.

26.12.2013

26 Ernst\&Young, "Kontrol Artık Müşteride", Global Bireysel Bankacılık Araştırması 2012 Türkiye Raporu, (http://www.ey.com/Publication/vwLUAssets/Global_Bireysel_Bankacılık_Araştırması_Türkiye_Raporu_2012/\$FILE/ey_GCBS_Bankacili kArastirmasi-240912-ekRapor-02.pdf)

27 Deloitte Social Analytics Tool, "Sosyal medya kitle bankacılığında yeni bir ufuk mu ?" (http://www.deloitte.com/view/tr_TR /tr/hakkimizda/index.htm) E.T. 20.05.2014 


\section{Acknowledgements}

This study was supported by Selcuk University Scientific Research Projects Coordination Unit with 14701287 project number.

\section{References}

http://www.sosyalmedyal.com,"Sosyal medya nedir?", (http://www.sosyalmedyal.com/2012/10/sosyal-medya-nedir.html\#.Uq3wyZBL5Ro) E.T. 10.11 .2013

http://tr.wikipedia.org, Sosyal Medya, (http://tr.wikipedia.org/wiki/Sosyal_medya) E.T. 09.10 .2013

Mike Fruchter, "Marketing On The Social Web: A Few Key Ingredients" 3 February 2009, (http://www.michaelfruchter.com/blog/) E.T. 10.09.2013

Burak Bayburtlu, "Sosyal Medya Nedir?", (http://www.burak.com/2009/06/23/sosyal-medya-nedir/) E.T. 06.10.2013

M. Andreas Kaplan, "If you love something, let it go mobile: Mobile marketing and mobile social media 4x4", Business Horizons, 55(2), 2012, p. 129-139.

Özgen ve Doymuş, a.g.e.,s.92

Communication Partner, "Doğru ve etkin bir iletişim pazar payınızı artıır." http://www.cpartner.com.tr/pazarlama-iletisimi/ E.T. 20.11.2013

Haluk Mesci, Reklamclık, T.C. Anadolu Üniversitesi, A.Ö.F. Yayını, Eskişehir, Ekim 1984, s.2

S.Inci ÇELEBI, Pazarlama Amaçlı Halkla Illişkiler ve Bütünleşik Pazarlama Iç̧indeki Rolü, Yüksek Lisans Tezi, Ege Üniversitesi, İzmir, 1999, s.10

Mustafa Duran, "Pazarlamada Yeni Bir Boyut: Bütünleşik Pazarlama Illetişimi", Pazarlama Dünyası, (http://www.pazarlamadunyasi.com/ Default.aspx?tabid=203\&ltemld=159) E.T. 11.02.2013

Cihad Yağmur Sadıkoğlu, "Reklamın Dönüşen Yeni Mecrası Açık Hava Reklamcıı̆ı ve Etkileri", İşletme Anabilim Dalı, Anadolu Üniversitesi Sosyal Bilimler Enstitüsü, Şubat 2013, (http://Acikhava-Reklamcilik.Webnode.Com.Tr/Makaleler/) E.T. 09.08.2013

Elif Uğurlu, "Reklamın İnsan Üzerindeki Etkisi", (http://okumagunlukleri.blogspot.com/2011/06/reklamn-insan-uzerindeki-etkisi.html) E.T. 01.11 .2013

Hugh Michael Jackman, Avustralyalı aktör ve yapımcıdır. Wolverine'i canlandırdığı X-Men filmlerinin dışında başrolde oynadığı Kate \& Leopold, Van Helsing, Prestij, Avustralya, Çelik Yumruklar, Sefiller ve Prisoners filmleriyle tanınır. Sefiller filmindeki performansı 2013'te ona En İyi Aktör dalında ilk Akademi Ödülü adaylı̆ııı ve Müzikal veya Komedi dalında En İyi Aktör dalında Altın Küre ödülünü kazandırdı.

H. Kemal Suher ve N. Bilge İspir, "Televizyon Ve Gazetede Reklamdan Kaçınmayı Etkileyen Değişkenler" Selçuk Üniversitesi, İletişim Fakültesi Akademik Dergisi, ISSN 1302-2865, Ocak 2010, Cilt; 6, Sayl; 2, s.6

Aziz Öztürk ve Ömer Faruk Güven, Bankacılık ve Sigortacılıkta Pazarlama, Beta Yayım A.Ş., İstanbul 2014, s.278.

Gresi Sanje Dahan ve Eser Levi, "Netnografya: Sosyal Mecralarda Tüketici Araşıtımaları Üzerine Yeni Bir Meto", T.C. Gümüşhane Üniversitesi, Iletişim Fakültesi Elektronik Dergisi, Mart 2012, Sayı;3, s.35

Emre Haliloğlu, "Finans ve Bankacılık Sektöründe İçerik Pazarlaması", Eva İstanbul İçerik Ajansı, (http://blog.turkcell.com.tr/finans-vebankacilik-sektorunde-icerik-pazarlamasi) E.T. 11.05.2014

Mike Sweeney, "What is Content Marketing and Why is it Hot?", Marketing Strategy, Fabruary 10, 2010, (http://www.rightsourcemarketing.com/marketing-strategy/what-is-content-marketing-and-why-is-it-hot/) E.T. 11.05.2014

Özgür Köseoğlu, "Bir Pazarlama Illetişimi Ortamı Olarak Facebook: Reklâm Ve Elektronik Ağızdan Ağıza Mesajların Karşılaştııımasına Yönelik Bir Analiz" Global Media Journal, ISSN1309-7601, Cilt; 3, Sayl; 6, Bahar 2013, s.76

Burcu IIter ve Habil Gökmen "Mevduat Bankalarında lilşkisel Fayda ile Müşteri Memnuniyeti Arasındaki liş̧ki Üzerine bir Inceleme: Izmir Ili Örneği', Dokuz Eylül Üniversitesi, Sosyal Bilimler Enstitüsü Dergisi, Cilt: 11, Sayı:1, 2009, s.5

Z. Beril Akıncı Vural ve Mikail Bat, "Yeni Bir İletişim Ortamı olarak Sosyal Medya: Ege Üniversitesi Illetişim Fakültesi'ne Yönelik Bir Araştırma", Journal of Yaşar University, Sayı: 20, No: 5, 2010, s. 3353.

(http://smgconnected.com/turkiye-diger-ulkelere-gore-e-ticaret-ve-sosyal-medya-kullanimindahangi -noktada) E. T. 09.09.2012

ING Bank Basın Bülteni 29 Haziran 2013, "Gençler Ödemelerini Sosyal Medya Aracılığıyla Gerçekleştirmek İstiyor", (http://www.ezonomics.com/img/iis/ingbank_bb_iis_180613_(2).pdf) E.T. 15.05.2014

Tunç Akyurt, "Küresel bankacılığın yükselen - değeri, Müşteri odaklı yaklaşım",Payment Systems Magazine (PSM), (http://psmmag.com/haber/musterileri-boyle-elinde-tutacak/590909) E.T. 10.05.2014

http://www.socialbakers.com ,Regional Reports: Turkey, Socialbakers Social Media Report, November 2013, (http://www.socialbakers .com/knowledge/reports/regional/november-2013-social-media-report-facebook-pages-in-turkey) E.T. 26.12.2013

Ernst\&Young, "Kontrol Artık Müşteride", Global Bireysel Bankacillk Araştırması 2012 Türkiye Raporu, (http://www.ey.com/Publication /vwLUAssets/Global_Bireysel_Bankacılık_Araştırması_Türkiye_Raporu_2012/\$FILE/ey_GCBS_BankacilikArastirmasi-240912ekRapor-02.pdf)

Deloitte Social Analytics Tool, "Sosyal medya kitle bankacilığında yeni bir ufuk mu ?" (http://www.deloitte.com/view /tr__R/tr/hakkimizda/index.htm) E.T. 20.05.2014 